\title{
Improving the colour fastness of the selected natural dyes on cotton
}

R. PRABHAVATHI, A. SHARADA DEVI AND D. ANITHA

Received: 21.10.2014; Revised: 27.03.2015; Accepted: 12.04.2015

See end of the paper for authors' affiliations

\section{R. PRABHAVATHI}

Department of Apparel and

Textiles, College of Home

Science, Acharya N.G. Ranga

Agricultural University, Saifabad,

HYDERABAD (TELANGANA)

INDIA
ABSTRACT : This paper reports the improving the colour fastness of the natural dye with dye fixing agents, extraction of the colourants from natural sources; effects of different mordants and mordanting methods; selection of fixing agents; dyeing variables; post-treatment process and analysis of colour improvement parameters with fixing agents for cotton dyed with natural dye; assessed colour improvement with rubbing colour fastness test.

KEY WORDS: Eucalyptus bark natural dye, Fixing agents, Colour fastness, Eco-friendly mordants

- HOW TO CITE THIS PAPER : Prabhavathi, R., Devi, A. Sharada and Anitha, D. (2015). Improving the colour fastness of the selected natural dyes on cotton. Asian J. Home Sci., 10 (1) : 240-244. 